\title{
XII
}

\section{THE CHRONOLOGY AND GENEALOGY OF THE MUHAMMADAN KINGS OF KASHMIR}

\author{
By Liedtenant-Colonel 'T. W. HAIG, C.M.G.
}

$\mathrm{M}^{\mathrm{R} .}$ STANLEY LANE-POOLE, on p. 311 of his most valuable work The Mohammadan Dynasties, has the following note after his list of the kings of Mālwa: "The list of the kings of Kashmir should follow here; but their chronology is so uncertain that an accurate table can hardly be constructed. See my Catalogue of the Coins of the Muhammadan States of India, xlvii, 68." It is evident, therefore, that the coins of this dynasty do not furnish us with sufficient materials for the construction of a complete chronological list of the kings of Kashmir, and Mr. C. J. Rodgers, writing in the Journal of the Asiatic Society of Bengal (lxv, pt. i, p. 225, 1896), says of them: "They are not of much value, as $I$ have shown elsewhere, for the assistance they render in fixing the chronology." I have, therefore, the less reason to regret my inability, far removed as I am from museums and libraries, to consult specimens and catalogues of these coins, and I propose, with the slender materials at my disposal, to make an attempt to solve some of the difficulties of this interesting question and to construct a tentative list of the lings of Kashmir which may at least form the basis of further investigation by those more fortunately situated than I am. My materials consist chiefly of the Tabaqât-i-Akbarī, Colonel Jarrett's excellent translation of the $\bar{A} \bar{\imath} n-i-A k b a r \bar{i}$, and Firishtah's history (Bombay text of 1830). The last-named can hardly be regarded as an independent authority, for Firishtah, in his account of this dynasty, is little more than a copyist of Nizām-al-dīn Ahmad, to whose Tabaqāt$i$-Akbari he has added little, but I have found his history Downloaded from https://www.cambridge.org/core. INSEAD, on 28 Mar 2018 at 13:49:08, subject to the Cambridge Core terms of use, available at https://www.cambridge.org/core/terms. 
useful for the reconstruction of various corrupt and defective passages in the text of my copy of the Tabaqät$i-A k b a r \bar{\imath}$, which is not one of the happiest efforts of the Newal Kishore Press of Lucknow.

The accepted date for the establishment in Kashmir, as minister to the Rāja Sinha Deva, of Shāh Mìrzā, the Muhammadan adventurer who afterwards seized the throne under the title of Shams-al-din and established a Muhammadan dynasty in that country, is A.H. 715 (A.D. 1315). The date of his seizing the throne, after defeating and capturing Rāni Kota Deva, the widow of Rãja Udyana Deva, is not expressly stated, but he died in A.H. 750 (A.D. 1349) after a reign of three years, or, according to the $\bar{A} \bar{i} n-i-A \not b b r \bar{i}$, two years eleven months and twenty-five days, so that A.H. 747 (A.D. 1346) may be accepted as the date of his establishment on the throne.

Shāh Mirzà left four sons, Jamshid, 'Alì Shīr, Shīrāshāmak, and Hindāl, of whom the eldest succeeded him, but retained the throne no longer than one year and two months, and was dethroned by his brother 'Ali Shir, whose accession, under the title of 'Alā-al-dīn, may thus be placed in A.H. 751 (A.D. 1350). The period of one year and ten months given in Colonel Jarrett's translation of the $\bar{A} \vec{\imath} n$ for the duration of Jamshid's reign is probably a misreading.

'Alä-al-din reigned for twelve years eight months and thirteen days, and was succeeded by his next brother, Shiräshāmak. This name, if it is correctly given by Nizām-al-dīn Aḥmad and Firishtah, was a childish nickname meaning "the little milk-drinker", and the prince's real name was doubtless Shihāb-al-dīn, by which he was known after his succession to the throne. The date of his accession, if we attempt to determine it by adding the duration given for 'Alā-al-dinn's reign to the year in which the latter ascended the throne, will be A.H. 763 (A.D. 1361-2) or A.H. 764 (A.D. 1362-3), but this Downloaded from https://www.cambridge.org/core. INSEAD, on 28 Mar 2018 at 13:49:08, subject to the Cambridge Core terms of use, available at https://www.cambridge.org/core/terms. 
date is too late by three or four years, as appears from certain events which occurred at the beginning of his reign. He is said to have defeated the Jām of Sind and to have established such a reputation as a warrior that the inhabitants of Qandahār and Gharni lived in dread of hin ; and then to have undertaken an expedition to the north-with what object is not clear-and to have penetrated the passes of the Hindu Kush, but to have been forced to return owing to the difficulties of the road. After his return he formed a cantonment on the banks of the Satlaj, and the Rajja of Nagarkot (Kängra), who was returning homewards after pillaging some of the districts of the empire of Dihli, met him and made submission to him. This expression, in a Muhammadan history of Kashmir, means no more than that the two monarchs met in a friendly manner and did not fight, but the date of the meeting is important, and can, I believe, be ascertained, at least approximately. In 1361 Fìñ $z$ Shāh of Dihli assembled his army for an expedition to Daulatābād, the town in which the amīrs of the Dakan had risen in rebellion against his cousin and predecessor, Muhammad bin Tughlaq, and had severed from Dihli the rich provinces of the south, but for some reason unexplained in the histories of his reign Fìnuz suddenly abandoned his intention of marching against Daulatābād and turned his arms against Kängra. It is certain that he would not have abandoned so important an enterprise as the expedition to Daulatäbād without good reason, and there can be little doubt that he had received grave provocation from the Rajja of Nagarkot, and that the provocation consisted in this impudent raid into imperial territory. The meeting between the Rāja of Nagarkot and Shihāb-al-din may thus be placed in A.D. 1361, so that it would have been impossible for Shihāb-al-dìn, if he did not ascend the throne until A.H. 763 or 764 , to carry out two distinct military enterprises and afterwards 
meet the Räja in A.D. 1361 on the banks of the Satlaj, and we must seek an earlier date for his accession. We have, fortunately, other materials, which enable us to fix a more probable date than A.H. 763 or 764 for this event. Shihāb-al-din reigned for twenty years and was succeeded by his brother Hindāl, who ascended the throne under the title of Qutb-al-din and reigned for fifteen years and tive months. The date of Hindāl's death is given by Firishtah (ii, 651) and perhaps also by Nizām-al-dîn Ahmad, though it does not appear in my imperfect copy of the Tabaqāt, as A.H. 796. Subtracting thirty-five years and five months, the sum of the two reigns, from this date we get A.H. 760 (A.D. 1359), and perhaps this may be accepted for the present as the date of Shihāb-al-din's accession. In this case his death must be placed in A.H. 780 (A.D. 1378-9) and Firishtäh's date (A.H. $796=$ A.D. 1393-4) retained for the death of his brother and successor, Quṭb-al-dìn Hindāl.

Hindāl was succeeded by his son, the bigot Sikandar, surnamed Butshikan, or the Iconoclast. The name by which he was known before his accession is given as Sakā, Sakār, or Sankār, probably a childish corruption of Sikandar. The events of the early years of his reign provide us with still further justification for selecting the earliest possible dates for his accession and that of his two predecessors. Sikandar was a child when he succeeded, and his succession to the throne was secured through the influence of his mother, Sūrah, an energetic lady who managed the affairs of the kingdom with a high hand, for in order to secure an undisturbed succession for her son she put to death her daughter and her daughter's husband. We know from the independent evidence of the Zafarnāmah of Maulānā Sharaf-al-dīn 'Alī Yazdì that Sikandar entered into relations with Taimūr-i-Lang on the occasion of the conqueror's retirement from Indja, after the capture of Dihli, in the early spring of A.D. 1399, 
and as it is nowhere indicated that the negotiations were conducted by a regent or guardian on behalf of Sikandar, and Sikandar himself set out to meet Taimūr and was only prevented by a misunderstanding from appearing before him personally in his camp, we must conclude that Sikandar was now of full age and was himself managing the affairs of his kingdom. It is therefore more probable that he succeeded in A.H. 796 than in A.H. 798 (A.D. 1395-6), the date obtained by adding the figures for the duration of the reigns of his two predecessors to the later date for the accession of Shihāb-al-din.

Sikandar reigned for twenty-two years and nine inonths, and A.H. 819 (A.D. 1416) may be accepted as the date of his death. He was succeeded by his eldest son, 'Alī Shāh, the duration of whose reign is given as six years and nine months, which would place his deposition in A.H. 826 (A.D. 1423), but, here again we have more trustworthy materials for establishing the date than the addition of the recorded duration of reigns to the date assigned for an accession. On the death of Sinha Bhat, the converted Brāhman who had, as minister of the kingdom, stimulated Sikandar's zeal against the misbelievers and had continued the same policy under his son, 'Ali Shāh resolved to perform the pilgrimage to Makkah, leaving his brother Shāhì Khān in charge of his kingdom. Whether he actually abdicated in his brother's favour or whether he merely left him in charge of the kingdom as regent is uncertain, but the Rāja of Jammū, who was 'Alī Shāh's father-in-law, induced him to forego his quixotic design of abandoning his kingdom, and, in conjunction with the Rajja of Rājāorì, provided him with a force to enable him to expel his brother. Shāhī Khān, on his brother's approach, fled from Kashmir and took refuge with Jasrat the Khokar, a chieftain who, with his brother Shaikhā, had incurred the wrath of Taimur by harassing his army instead of fulfilling his promise to help him, and had 
accordingly been carried off into captivity in Samarqand, whence he had escaped after 'Taimūr's death in A.H. 807 (A.D. 1404-5). Jasrat, who had regained his power and influence in the Northern Panjāb, espoused Shāhī Khān's cause and marched with him towards Srinagar, and 'Ali Shāh marched to repel the invaders, and, in his haste to meet them, foolishly exhausted his army by a long forced march. Shāhī Khän and his ally, on learning the condition of their enemy, at once attacked him in the hills near the Tattakuti Pass and gained a complete victory. 'Ali Shāh's fate is uncertain. According to one account he escaped, but according to others, more probable, he was captured. by Jasrat's troops. In either case he is no more heard of, and Shāhi Khān, with Jasrat's help, ascended the throne under the title of Zain-al-'A bidin. According to the history of the Sayyid emperors of Dihli, the battle between the two brothers was fought in the month of Jamädi-al-awwal, A.H. 823 (May-June, 1420), and we may confidently accept this date as that of the accession of Zain-al-'Äbidin, for immediately afterwards we find Jasrat, with his assistance, beginning a course of aggression against the dominions of Mubārak Shāh of Dihlī. Zain-al-'Ābidin, the Akbar of Kashmir, is said to have reigned for fifty-two years, and we may assume that the duration of his reign is correctly stated and that he died in Jamädi-al-awwal, 875 (November-December, 1470), for this date agrees with

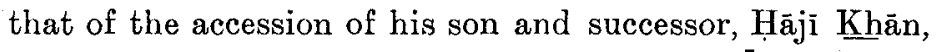
as determined by legends on coins. ${ }^{1}$ Zain-al-'Ā bidin's age at the time of his death is given by Firishtah (ii, 665) as 68 (lunar) years, so that at the time when Jasrat the Khokar helped him to ascend the throne he was a youth of 16 .

1 See JASB. Ixv, pt. i, p. 225, 1896. This is one of only three instances in which $I$ have found legends on Kashmĩr coins helpful. 
Hăjji Khān ascended the throne three days after his father's death under the title of Haidar Shāh. $\mathrm{He}$ is wrongly styled in the $\bar{A} \bar{\imath} n-i-A k b a r i \bar{i}$ (ii, 379) "Hāji " Haidar Shāh. Hạji Khān was his personal name, and should not be prefixed to the name which he bore as king as though it were the title appropriated to those who have perforfned the pilgrimage to the sacred cities of Islam. After a reign of one year and two months he slipped when he was drunk on the polished floor of a hall and died of the injuries which he received in Rajab, 876 (December, 1471-January, 1472). This date, obtained by adding the duration of his reign to the date ascertained as that of his succession, is corroborated by legends, on the coins of his son and successor, Hasan Shäh, the duration of whose reign is unknown to Nizām-al-din Ahmad and Firishtah, so that we are obliged to ascertain the date of the accession of his son, Muhammad Shāh, by means other than the simple process of adding the duration of Hasan's reign to the date of his accession. The next king the date of whose accession may be satisfactorily determined by contemporary events is Ibrāhim Shāh, who was a refugee at the court of the Lodi emperors of Dihlī, and, on the defeat of Ibrāhim Lodi by Bābur at Pānipat on Rajab 6, 932 (April 18, 1526), returned to Kashmir and was immediately enthroned in the place of Muhammad Shāh, then occupying the throne for the third time. Ibrāhim Shäh's accession may be placed late in A.H. 932 (A.D. 1526), and the sum of the reigns which intervened between Muhammad Shāh's first accession and the accession of Ibrāhim Shāh is thirty-eight years. This, subtracted from A.D. 932, the date determined as that of Ibrāhim's accession, gives A.H. 894 (A.D. 1489) as the year of Hasan Shāh's death and Muhammad Shāh's first accession. The duration of Muhammad Shāh's first reign is said to have been ten years and seven months 
but as the date of his deposition is given in the Tabaqāt$i$-Albbari as A.H. 894 (A.D. 1489) we may presume that "ten years and seven months" is a scribe's error for ten months and seven days. Muhammad was succeeded by his father's cousin german, Fath Shāh, who was deposed after a reign of nine years, that is to say in A.H. 903 (A.D. 1497-8), when Muhammad was restored, but reigned for only nine months and nine days, until late in A.H. 903 or early in A.H. 904 (A.D. 1498), when Fath Shāh was restored and reigned for one year and one month until A.H. 904-5 (A.D. 1499), when Muhammad was again restored. The duration of Muhammad Shāh's third reign is said to have been fifteen years eleven months and eleven days, or nearly sixteen years, but as he was succeeded by Ibrāhim Shāh, the date of whose accession, as already determined, was A.H. $932^{\circ}$ (A.D. 1526), its duration was actually between twenty-seven and twentyeight years.

The reign of Ibrähim lasted only for eight months and some days when, according to Nizām-al-din Ahmad's and Firishtah's chronicles of Kashmir, he was defeated and overthrown by a force sent by Bābur, under Shaikh 'Alī Baig, Muḥammad Khān, and Maḥmūd Khān. This event is not mentioned in histories of the reign of Bābur, but from the chronicles of Kashmir it would appear that Abdāl Mākarī, a discontented amīr of Kashmir, had sought help from Bābur against Kājī Chak, who had helped to depose Mụ̣ammad Shāh and place Ibrāhim on the throne, and against Ibrāhim himself, who had been a protégé of the Lodiss, and that Bābur had assisted him in the manner described. It seems highly improbable that Bābur, who required all his troops to establish himself in his newly conquered empire, should have spared a large force for the conquest of Kashmir, but Kashmir had been for some time past the prey of factions, and it is possible that Bābur gave permission Downloaded from https://www.cambridge.org/core. INSEAD, on 28 Mar 2018 at 13:49:08, subject to the Cambridge Core terms of use, available at https://www.cambridge.org/core/terms. 
to some of his amirs in the Panjāb or at Kābul to supply such a force as would suffice to destroy the balance between two contending parties and to place on the throne of Kashmir a prince who might be regarded as a nominee of his own.

In a battle fought in A.H. 933 (A.D. 1527) in the pargana of Bānkil, Ibrāhīm Shāh's army was utterly defeated and Ibrāhim, himself either slain or forced to flee, for of his fate nothing is known and he is never heard of again. Abdāl Mākarís candidate for the throne was a prince named Nāzuk, who thus succeeded in A.H. 933, but did not long retain the throne. The duration of his first reign is given in my copy of the Tabaqa $\bar{a}-i-A l b b a r \bar{\imath}$ as twenty years, but this is impossible, for one of the best-ascertained dates which we have in the history of Kashmir is that of its conquest by Mirza Haidar the Mughul, who captured Srinagar and began to reign there on Rajab 22, 947 (November 22, 1540). The Bombay text of Firishtah clumsily expresses the duration of Näzuk Shāh's first reign as "twenty years and twenty months", an expression which must almost necessarily be a misreading, for no writer would describe such a period otherwise than as "twenty-one years and eight months"; but this misreading in Firishtah suggests the correct meaning, which will enable us to correct the Tubaqāt also. A careless copyist, one of the class well known to students of Persian MSS. and lithographed editions, might very well substitute "years" for "months", and a second representative of the same class, seeing "years" in one MS. and "months" in another, might easily solve the difficulty for himself by writing both. I believe, then, that the correct reading is "twenty months", an expression which might very well be used for the sake of brevity instead of "one year and eight months", and my reason for selecting this reading is that it enables us to arrange the reigns during 
this period of confusion in such a manner that they fit in with the few known dates at our disposal. Assuming, then, that Nāzuk Shāh occupied the throne on this occasion for a year and eight months, we arrive at the conclusion that Muhammad Shāh, who had taken refuge in Loharkot and was brought thence and restored by Abdāl Mākari, ascended the throne for the fourth time in A.H. 935 (A.D. 1529). The approximate correctness of this date is established by Nizām-al-din Ahmad's statement that the death of Bābur, which occurred on Jamādial-awwal 5, 937 (December 25, 1530), occurred shortly after Muhammad Shāh's third restoration.

The duration of Muhammad Shăh's fourth reign is not given, and both Nizâm-al-din Aḥmad and his plagiarist, Firishtah, conclude their notices of it by recording that he reigned for fifty years, a term which must necessarily be referred to the period which had elapsed since his first enthronement, placed by me in A.H. 890 (A.D. 1485), for it is certain that this much-harassed roi fainéant, who closed his fourth reign by a death which was possibly as welcome to him as to his chroniclers, did not reign for tifty years after his third restoration. The date of his death is not given, but it appears from the chronicle of his reign to have occurred in A.H. 941 (A.D. 1534-5), and if this date be accepted we are enabled to apply a check to the date assigned by me to his first elevation to the throne, viz. A.H. 890 (A.D. 1485). Subtracting fifty years from A.H. 94l we get A.H. 891 (A.D. 1486), which is sufficiently near to the date already given for his first accession to render it unnecessary to revise the calculation by which that date was determined.

There is yet another event which will help to fix the date of Muhammad Shäh's death. At the close of his reign, evidently in the year before his death, the appearance of two comets is recorded. The year in which this phenomenon occurred is given by Niẓam-al-din A.̣mad as Downloaded from https://www.cambridge.org/core. INSEAD, on 28 Mar 2018 at 13:49:08, subject to the Cambridge Core terms of use, available at https://www.cambridge.org/core/terms. 
A.H. 939 (A.D. 1532-3), and the date can thus be verified by astronomical records, to which $I$ have at present no access.

Muhammad Shāh was succeeded by his son Shams-aldin, the account of whose reign is most unsatisfactory. No duration is given, and Nizām-al-dīn Aḥmad, after recording a few events, remarks, "This is all that has been found in the history of Kashmir regarding Sultān Shāms-al-din." We are not told whether the reign came to an end by the king's death or by his deposition, but as he never again appears on the scene it is probable that he died. Fortunately we have satisfactory data for determining the duration of the reign, for he was succeeded by Nāzuk Shāh, the king of that name who had already reigned once and who now reigned for only five or six months, at the end of which period he was expelled by Mirzā Haidar the Mughul, who, as has already been stated, occupied Srinagar on Rajab 22, 947 (November 22, 1540), so that Shams-al-din ceased to reign and Nāzuk succeeded him early in that year, either in Șafar or Rabi-al-awwal (June or July, 1540).

My authorities for the date of Mirzā Haidar's occupation of Kashmīr are Nizām-al-din Ahmad and Budāoni, and the date could probably be veritied from the Alkarnāmah. Mirzā Haidar, the son of Muhammad Husain, who was the son of Bābur's maternal aunt, was a poet. and the author of the well-known history, Tari $\bar{z} k h_{-}-i$ Rashizdi. He invaded Kashmīr, with Khwāja Kalān Baig, under the auspices of Humāyūn, who was now at Lāhor, having been expelled from Hindüstān by Shīr Khān Sūr, and Kāmrān Mìrzā, Humāyūn's brother, and at the invitation of a party among the amirs of Kashmir. The duration of Mirzā Haidar's reign in Kashmīr is always given as ten years, but as it is certain that he was slain in A.H. 958 (A.D. 1551) he actually occupied the throne for ten years and some months. 
After Mīrzä Haidar's death Nāzuk Shāà was again restored, and, according to my copy of the Tabaqãt-iAlibari, reigned on this occasion for only two months, but the variant in Firishtah, ten months, is probably the correct reading. He was finally deposed in A.H. 959, before Shawwāl 1 (September 20, 1552), which date is given for an event which occurred early in the reign of his successor, Ibrāhīm Shāh, who, as we shall see hereafter, was probably his son. This Ibrāhim must not be confounded with the former Ibrāhim Shāh, son of Muhammad Shāh, who, as has been seen, disappeared entirely in A.H. 933. Ibrāhim II is said to have reigned for only five months, but as a severe earthquake which occurred in Kashmir in A.H. 962 (A.D. 1555) is mentioned among the events of his reign it is clear that he was not deposed until that year, when Ismāiil Shāh, described as his brother, was raised to the throne. He reigned for two years and died late in the year A.H. 964 (A.D. 1557), when he was succeeded by his son Habib Shāh, the last of his line. The kings of the line of Shāh Mirzā had long been mere puppets in the hands of rival families in Kashmirr, and as each faction obtained power it dethroned the reigning monarch and placed its own candidate on the throne. Hitherto it had always been considered necessary that the throne should be filled by some scion of the old royal line, but by the year A.H. 968 (A.D. 1561) the Chak clan had obtained complete predominance in the state and had so consolidated their power that Ghāzi Khān Chak, the virtual ruler of the kingdom, was able to dethrone and imprison Habib Shāh and to ascend the throne under the title of Ghāzi Shāh.

Ghāzi Shāh was a leper, and owing partly to the incapacity caused by his disease and partly to the embitterment of his temper from the same cause, which rendèred him obnoxious to his people, he decided in A.H. 971 (A.D. 1563-4) that he was no longer fit to reign Downloaded from https://www.cambridge.org/core. INSEAD, on 28 Mar 2018 at 13:49:08, subject to the Cambridge Core terms of use, available at https://www.cambridge.org/core/terms. 
and abdicated in favour of his brother Husain, who ascended the throne under the title of Nașir-al-din. The date of his accession is one of the few corroborated by legends on coins. Nașir-al-din Husain Shāh fell sick in A.H. 977 (A.D. 1569-70) and quarrelled with his brother 'Ali, who dethroned him, and Ilusain died shortly afterwards. 'Alī Shāh died in A.H. 986 (A.D. 1578-9) and was succeeded by his son Yūsuf Shăh, whose reign was disturbed both by intestine feuds and by foreign interference. Sayyid Mubārak Khān, a usurper, seized the throne in A.H. 986 (A.D. 1579) and was deposed in the following year, when another usurper, Lohar Chak, of Yūsuf's own clan, seized the throne, but was deposed by Yüsuf in the same year (A.H. $987=$ A.D. 1580).

Missions were interchanged more than once between Yuusuf Shāh and Akbar, who was resolved to annex Kashmir to his empire, and in A.D. 1584 Yūsuf sent his son Ya'qūb to Akbar's court. Late in 1585 Akbar sent an expedition under his kinsman Shāhrukh Mirzā and Rāja Bhagwān Dās to conquer Kashmirr, and Yūsuf Shāh, after preparing to oppose the invaders, abandoned his intention and agreed to pay tribute to Akbar. Leaving his son Ya'qūb, who had returned to Kashmir, as his regent, he joined the imperial troops and was escorted to Akbar's court, where he was presented on April 7, 1586. Akbar, who had been resolved to reduce Kashmir to the status of a province of the empire, and had had no intention of allowing it to retain even the measure of independence enjoyed by a tributary state, was much displeased with his officers for having so readily accepted Yásuf's submission and for not having conquered the country, and refused to ratify their treaty with Yüsuf, whom he perfidiously detained as a prisoner at his court, so that $\mathrm{Ya}^{\prime} q \mathrm{u}$ b continued to reign in Kashmir. In A.D. 1587 Akbar sent another expedition, under Muhammad Qāsim Khān, Mïr-i-Bahrr, into Kashmir, and Ya'qūb, who was Downloaded from https://www.cambridge.org/core. INSEAD, on 28 Mar 2018 at 13:49:08, subject to the Cambridge Core terms of use, available at https://www.cambridge.org/core/terms. 
prepared to defend his throne, was prevented from doing so by the wholesale desertion of his amirs to the imperial camp, and by a rebellion which enabled Muhammad Qāsim Khān to occupy the capital without opposition. Ya'qūb fled to the hills, and, after evading the pursuit of the imperial officers for two years, surrendered himself and was carried to Akbar, before whom he made his submission on August 8, 1589. Yūsuf, Ya'qūb's father, had already entered Akbar's service in the humble position, for one who had occupied a throne, of a commander of 500 horse with a jāgīr in Bihār.

The genealogy of the kings of Kashmir is little less complicated than their chronology. The earlier kings of the first dynasty offer little difficulty, but it is not easy to trace the parentage of the puppets who were enthroned, deposed, and again enthroned in rapid succession by conflicting factions. Shāh Mìzā, Shams-al-din, the founder of the dynasty, had four sons, Jamshid, 'Ali Shìr, Shìrāshāmak, and Hindāl, who followed him on the throne in the order of their birth. Of these the third son

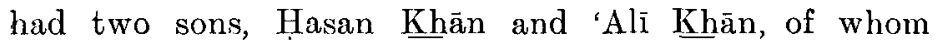
nothing further is known. Hindāl, the fourth son, had two sons, Sikandar, who succeeded him and carried on the line, and Haibat Khān, who was poisoned. Sikandar had three sons, Mir Khän, who succeeded him under the title of 'Alī Shāh and died, apparent.ly childless, Shāhì Khān, who succeeded 'Alī Shāh under the title of Zain-al'Ābidin, and Muhammad Khăan, who had a son named Haidar Khān, neither of whom figures in history. Zainal-'Ábidin had three sons, of whom the youngest, Bahrām Khān, was blinded and died in prison and had a son, Yūsuf Khān, who was poisoned. Zain-al-'Ābidin's two elder sons were Ādam Khān and Hāji Khān, of whom the latter succeeded his father under the title of Haidar Shāh. The eldest son never succeeded to the throne, but had a son, Fath Khān, who reigned twice, and had a son, 
Iskandar Khän, who was blinded. It is probable, too, that Nāzuk Shāh, who reigned three times, from 1527 to 1529 , in 1540 , and from 1551 to 1552 , was a son of Fath Shäh. He is so described in the heading to his first reign in the Tabaqa $\bar{a} t-i$-Akbar $\bar{i}$ and in the $\bar{A} \bar{\imath} n-i-A k b a r \bar{\imath}$, but his parentage is not beyond doubt. Firishtah (ii, 675) styles him the son of Ibrāhim Shāh, the son of Muhammad Shāh, but it was this Ibrāhim Shāh who was defeated in 1527 by the Mughul amirs Shaikh 'Ali Baig, Muhammad Khān, and Mạ̣mūd Khān, assisting the Kashmīrì amīr Abdāl Mākarì, whose candidate for the throne was Nāzuk, and it is more probable that Nazuk belonged to the rival branch of the royal family and was the son of Fath Shāh than that he was the son of Ibrähim in the camp of his father's enemies, but the question is still full of difficulty. Nizām-al-din Ahmad says, at the end of his account of the reign of Shams-al-din Shāh (A.D. 1534-40), "after him his son, Nāzuk Shāh, sat on the throne," and this statement is repeated by Firishtah (ii, 678), though he has already described Nāzuk Shāh as the son of Ibrāhīm and expressly states that Nāzuk's reign in 1540 was his second, so that we have no fewer than three fathers assigned to Nāzuk Shāh, one of whom, Ibrāhīm, may be definitely eliminated. We might surmount the difficulty by assuming that there were two Nāzuks, one the son of Fath Shäh and the other the son of Shams-al-din, but against this assumption we have Firishtah's headings to the reigns of A.D. 1540 and A.D. 1551-2, which he describes as the second and third reigns of Nāzuk Shāh. This difficulty is not of much importance, for Firishtah is slipshod and inaccurate; but I hesitate to assume that the uncommon name of Näzuk was repeated in the royal family of Kashmir, and prefer to regard Nizām-al-dín Ahmad's statement that Shams-al-din was succeeded by " his son" Nāzuk either as a careless slip on the part of the author, who may have almost mechanically described Downloaded from https://www.cambridge.org/core. INSEAD, on 28 Mar 2018 at 13:49:08, subject to the Cambridge Core terms of use, available at https://www.cambridge.org/core/terms. 
a king as the son of his predecessor, or as an interpolation by a careless scribe. In either case Firishtah's repetition of the error would be of no consequence.

Zain-al-'Ābidin's second son, Ḥāji Khān, who succeeded him under the title of Haidar Shāh, had a son named Hasan Khän, who succeeded him under the title of Hasan Shāh, and Hasan had two sons, Muhammad, who succeeded him, and reigned no less than four times, and Husain Khān, of whom nothing more is heard. Muhammad Shāh had two sons, Ibrāhim, who reigned from 1526 to 1527 , and Shams-al-din, who reigned from 1534 to 1540 . Shāms-al-din seems to have left no son, for the supposition that Nāzuk was his son has been rejected. Nāzuk appears to have had two sons, Ibrāhim and Ismāinl, both of whom ascended the throne, but the question of their parentage is not free from difficulties. Both Nizām-al-din Aḷmad and Firishtah say that the Ibrāhim who was the son of Muhammad Shāh and who reigned from 1526 to 1527 and was then defeated by the Mughul amirs, disappeared completely and that his fate is unknown, but both afterwards contradict themselves by stating that the Ibrähim who reigned in 1552 was the son of Muhammad, thereby clearly suggesting his identity with the Ibrāhim who had disappeared. Firishtah further contradicts himself by stating in a heading (ii, 685) that the reign of 1552 was Ibrāhim's third reign, a manifest inaccuracy, though he immediately afterwards describes this Ibrāhim as the son of Nāzuk Shāh. Nizām-al-din Aḥmad, though he commits himself once to the statement that this Ibrāhim was the son of Muhammad Shāh, describes him elsewhere as the brother of Nāzuk Shāh and the brother of Ismāîl Shäh. There is no reason for believing that he was the brother of Nāzuk, but there is every probability that he was the brother of Ismā'il and therefore the son of Näzuk, as stated by Firishtah, who seems. in this instance, to have preserved for us the correct reading. 'The conclusion, Downloaded from https://www.cambridge.org/core. INSEAD, on 28 Mar 2018 at 13:49:08, subject to the Cambridge Core terms of use, available at https://www.cambridge.org/core/terms. 
therefore, at which I have arrived is that there were two Ibrāhims, one the son of Muhammad Shāh and the other the son of Nāzuk Shāh. Ibrāhīm II, who reigned from 1552 to 1555 , seems to have left no son, and was succeeded by his brother Ismäìl, who reigned from 1555 to, 1557 and was succeeded by his son Habib Shāh, with whom the dynasty came to an end in A.D. 1561.

The genealogy of the short-lived Chak dynasty presents fewer difficulties than that of the house of Shāh Mirzā, for the only question which arises is the paternity of Ghāzi Khān Chak, its founder. The founder of the fortunes of the Chak clan in Kashmīr was Käjî Chak, who was kingmaker during the reigns of some of the later kings of the older line. During the third reign of Nāzuk Shāh, and just after the downfall and death of Mirzā Haidar, Shankar Chak, son of Kājī Chak, who, in the partition of the spoil which ensued on the expulsion of the Mughuls, had received no fief, quarrelled with Ghāzi Chak, who originally owed his position in the clan largely to his being commonly accepted as a son of Kajji Chak, whereas he was not in fact his son, but the son of the wife of Hasan Chak, the brother of Kāji. Kāji married his brother's widow during her pregnancy, Ghāzi being born two or three months after the marriage, so that he was known to be the son of Hasan. Käjì's action, though a breach of the Islamic law, amounted in fact to an acknowledgment or an adoption of Ghāzi Khān as his son, and by the time when Shankar attempted to question Ghāzi's paternity the latter's predominance in the clan was so assured that the attempt failed, despite the common knowledge that Ghäzi was, in fact, the son of Hasan. Husain and 'Alī, the two brothers who ascended the throne in succession after Ghäzi, were almost certainly younger than Ghāzi, and were therefore perhaps the sons of Hasan Chak's widow by her second husband, Käji Chak, and the half-brothers of Ghäzì Khān. 'Alī was 
succeeded by his son Y $\mathrm{u}$ suf, and Yùsuf by his son Ya'qūb, the last of the Chak dynasty.

In the appended tables I have followed the example of Mr. Stanley Lane-Poole in plaeing the Hijrah dates on the left and the Christian dates on the right of the columns of names.

\section{First Mohammadan Dynasty of Kashmīr}

A.H.: $\quad$ A.D.

.747. 1. Shāh Mirzā, Shams-al-dīn . . . 1346

750. 2. Jamshīd . . . . . . . . 1349

751. 3. 'Alī Shīir, 'Alä-al-dīn . . . . 1350

760. 4. Shīrashämak, Shihāb-al-dïn . . 1359

780. 5. Hindāl, Qutb-al-dīn . . . . 1378

796. 6. Sikandar, Butshikan . . . . 1393-4

819. 7. Mīr Khān, 'Alī Shāh . . . . 1416

823. 8. Shāhī Khān, Zain-al-'Ābidīn . . 1420

Jumādī 1, 875. 9. Hājī Khăn, Haidar Shāh . Nov،-Dec. 1470

Rajab, 876. 10. Hasan Shāh ". Dec. 1471 or Jan. 1472

894. 11. Muhammad Shāh . . . . 1489

894. 12. Fath Shāh . . . . . 1489

903. 11. Muhammad Shăh, restored . . . 1497-8

903-4. 12. Fath Shāh, restored . . . . 1498

904-5. 11. Muhammad Shāh, again restored . T499

932. 13. Ibrāhīm Shāh 1 . . . . . . 1526

933. 14. Nāzuk Shāh . . . . . 1527

935. 11. Muḥammad Shāh, again restored $\quad 1529$

Safar or 941. 15. Shams-al-dĩn Shāh II . . . . 1534-5

Rabī 1, 947. 14. Nãzuk Shāh, restored. . June-July, 1540

Rajab 22, 947. 16. Mīrzạ Haidar, usurper . . Nov. 22, 1541

958. 14. Nāzuk Shăh, again restored . . 1551

959. 17. Ibrāhīm Shāh II $\quad . \quad$. $\quad . \quad$. 1552

962. 18. Ismā'il Shāh . . . . . . 1555

964. 19. Habīb Shāh . . . . : 1557

-968 . -1561

2. Chak Dynasty

968. 1. Ghāzī Shāh . . . . . 1561

971. 2. Nașir -al-dīn Ḥusain Shāh . . . 1563-4

977. 3. 'Alì Shāh . . . . . . 1569-70

986. 4. Yūsuf Shāh . . . . . . 1578-9

993. 5. Ya'qūb Shāh . . . . . . 1585

$-997$.

[MUGHUL EMPRRORS] 


\section{First Mupammadan Dynasty of Kashmīr}

(Small Roman numerals indicate the various reigns of those kings who reigned more than once.)
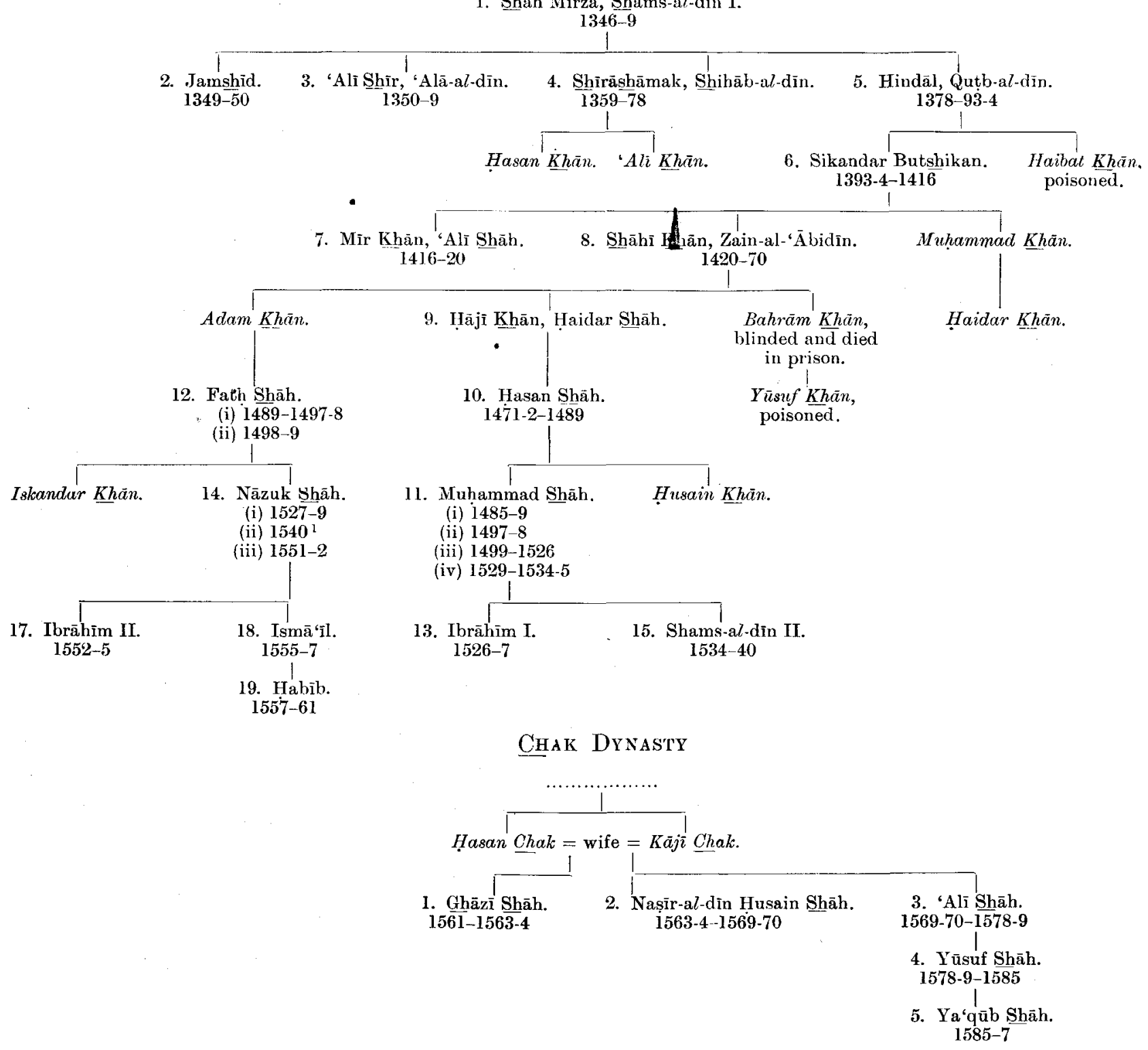

1 Usurpation of Mīrzā Haidar, 1540-51. 